\title{
TESTING SIMILARITY COEFFICIENTS FOR ANALYSIS OF THE FOSSIL RECORD USING CLUSTERING METHODS: THE PALAEOZOIC FLORA AS A STUDY CASE
}

\author{
Borja CASCALES-MIÑNA \\ Department of Plant Biology, University of Valencia. Av/ Vicente Andrés Es- \\ tellés s/n, 46100 Burjasot (Valencia), Spain. borja.cascales@uv.es
}

Cascales-Miñana, B. 2010. Testing similarity coefficients for analysis of the fossil record using clustering methods: the Palaeozoic flora as a study case. [Evaluando coeficientes de similitud para el análisis del registro fósil usando métodos de agrupamiento: la flora del Paleozoico como caso de estudio.] Revista Española de Paleontología, 25 (1), 19-34. ISSN 0213-6937.

\begin{abstract}
This paper reports a global methodological approach based on the similarity and clustering methods of the Palaeozoic plant fossil record using a comparative approach between two similarity measures: the Jaccard and Raup-Crick Coefficients. The results show that although the Raup-Crick Coefficients clearly have the potential for providing more robust results, the consequences of the extinction processes are better reflected in the similarity analysis based on the Jaccard Coefficients. On the other hand, the cluster analysis based on UPGMA algorithm shows four robust clusters and reveals new evidence for the singularity of Mississippian flora. Finally, the results obtained reveal that similarity and cluster analysis are powerful tools to interpret the consequence of the processes modifying the taxonomic composition of the several analyzed Palaeozoic time units.
\end{abstract}

Key words: Evolutionary innovations, extinction processes, multivariate analysis, Palaeozoic, fossil record, similarity.

\section{RESUMEN}

Este artículo divulga una aproximación metodológica global basada en los métodos de similitud y agrupamiento del registro paleozoico de las plantas vasculares mediante un análisis comparativo entre dos medidas de similitud: el índice de Jaccard y el de Raup-Crick. Los resultados demuestran que aunque los coeficientes de RaupCrick presentan claramente un mayor potencial para proporcionar resultados más robustos, las consecuencias de los procesos de extinción se reflejan mejor en los análisis de similitud basados en los coeficientes de Jaccard. Por otra parte, el análisis de agrupamiento basado en el algoritmo UPGMA revela cuatro clusters robustos junto con nueva evidencias de la singularidad de la flora del Misisípico. Finalmente, los resultados obtenidos revelan que los análisis de similitud y agrupamiento son poderosas herramientas para interpretar las consecuencias de los procesos que modifican la composición taxonómica de las distintas unidades de tiempo analizadas del Paleozoico.

Palabras clave: Innovación evolutiva, procesos de extinción, análisis multivariable, Paleozoico, registro fósil, similitud.

\section{INTRODUCTION}

In the second half of the past century, several authors published a series of articles which today comprise the most recent history of palaeontological and evolutionary science (Raup, 1972, 1975, 1978, 1985; Van Valen, 1972, 1973a, 1973b; Raup \& Stanley, 1978; Sepkoski, 1978, 1979, 1984, 1987, 1993, 1994, 1997, 1998; Raup \& Crick, 1979; Raup \& Boyajian, 1988). The methodolo- gies proposed in these papers are currently still in use, but undergoing continuous revision, in order to optimized the information obtained from the fossil record about evolutionary patterns and process.

In recent years, numerical and multivariate methods have played an important role in palaeontological analysis. These methods now go far beyond the diverse fields of morphological and phylogenetic analyses to embrace biostratigraphy, palaeobiogeography, and palaeoecology 
(Sepkoski \& Kendrick, 1993; Miller \& Foote, 1996; Roth \& Mosbrugger, 1996; Kramer \& Konigsberg, 1999; Mertz et al., 2000; Sepkoski et al., 2000; Valentine \& Jablonski, 2003; Marui et al., 2004; Ruíz et al., 2004; Palmqvist et al., 2008; Figueirido et al., 2009; Frobisch, 2009; among others). In this sense, recently published papers emphasise the use of clustering methods in palaeogeographical and palaeoecological applications to provide a better, detailed vision of the assemblages at specific times of the geologic time (Dimitrova \& Cleal, 2007; Hilton \& Cleal, 2007; Cleal, 2008a, 2008b; Coiffard et al., 2008). Here I use similarity and clustering methods to bring a general vision of the Palaeozoic plant fossil record with a methodological comparative approach.

\section{MATERIAL AND METHODS}

\section{DATA SOURCES}

In agreement with several classic palaeobiological papers of the twentieth century, which use compiled data from the monographic literature (Newell, 1952; Simpson, 1953; Müller, 1961; Schindewolf, 1962; Valentine, 1969), the Palaeozoic plant fossil record has been analysed based on several classic monographic studies (Cleal, 1993a, 1993b; Stewart \& Rothwell, 1993; Taylor \& Taylor, 1993; Cleal \& Thomas, 1994, 1999). This paper has been conducted at the family level; the taxa used are specified in Table S1. In accordance with recently published works (Kvaček et al., 2006; Willis et al., 2007; Jud et al., 2008; Wagner \& Álvarez-Vázquez, 2008), the taxonomy used in the present paper follows that of Cleal (1993a, 1993b) in "The Fossil Record 2". To minimize the taxonomic, sampling and rock record bias (Raymond \& Metz, 1995; Foote, 1997; Lane \& Benton, 2003; Wang \& Bush, 2009), inherent to this methodology, several types of fossils were considered for each taxon in the sample (Benton, 1993; Taylor et al., 2009) taking into account vegetative and reproductive structures in order to diminish the possible taphonomic effect regarding to the preservation bias; see Table S1 for details. Detailed information about this methodological bias can be consulted from CascalesMiñana et al. (in press).

The data were codified in a primary double-entry matrix from floristic lists by placing the taxa in rows and the time units in columns, in agreement with Digby \& Kempton (1987) and Kovach (1988). Recent articles have used the binary nomenclature to codify the data (Hilton \& Cleal, 2007; Cleal, 2008a; Coiffard et al., 2008). According to this methodology, each box of the matrix takes a value of one or zero when the taxa are either present or absent in a time unit. The present analysis includes nine time units of the geological time scale (Gradstein \& Ogg, 2004). The time units have been named according to the International Commission on Stratigraphy's time-rock term, and the discussion has been written accordingly. Absolute ages have been extracted from Gradstein \& Ogg (2004). For detailed absolute ages and information about the time units see Table 1.

Table 1. Temporal range of the analysis of Palaeozoic flora, time units and abbreviations. Absolute ages extracted from Gradstein \& Ogg (2004).

\begin{tabular}{cclc}
\hline Time Units & Abbreviation & \multicolumn{2}{c}{ Ages (Myr) } \\
\hline Late Silurian & US & 428.2 & 416.0 \\
Early Devonian & LD & 416.0 & 397.5 \\
Middle Devonian & MD & 397.5 & 385.3 \\
Late Devonian & UD & 385.3 & 359.2 \\
Mississippian & LC & 359.2 & 318.1 \\
Pennsylvanian & UC & 318.1 & 299.0 \\
Early Permian & LP & 299.0 & 270.6 \\
Late Permian & UP & 270.6 & 251.0 \\
Early Triassic & LT & 251.0 & 245.0 \\
\hline
\end{tabular}

\section{SIMILARITY AND CLUSTER ANALYSIS}

Traditionally, Jaccard Coefficients have been regarded as the most reliable similarity coefficient for presence-absence data which are a measure of the proportion of elements (taxa) that two objects (time units) have in common (Shi, 1993; Cleal \& Shute, 1995; Thomas, 2007). Nevertheless, problems arise when the Jaccard coefficients are used to compare two samples when one has considerably more taxa than the other (Hammer \& Harper, 2006). One alternative is to use the Raup-Crick Coefficient, which is calculated using a "Monte-Carlo" randomization procedure, to determine how often a comparable level of similarity occurs in two hundred randomly replicated samples of the same size (Raup \& Crick, 1979). This statistical probabilistic index is the confidence level associated with a unilateral randomization test, which involves, for each pair of time units compared (Maridet et al., 2007). The general procedure cited by the literature specify that when a couple of time units appear characterized by a very high Raup-Crick index value (say, $R C>0.95$ ) show a significant similarity between their studied taxonomic composition (they nonrandomly share too many taxa in common); in contrast, a couple of time units characterized by a very low RaupCrick index value (say, $R C<0.05$ ) show a significant difference between their studied taxonomic composition (they non-randomly share too few taxa in common), which can be interpreted as a measure of the robustness (Costeur et al., 2004; Maridet et al., 2007; Costeur \& Legendre, 2008). Therefore, for each pair of time units, the associated null distribution of the number of shared families was estimated by generating 10,000 successive random resamplings 
from the common pool of families without taking into account the observed probabilities of taxa occurrence. In other words, it provides an estimate of the likelihood of the observed similarity between the two samples occurring through a random selection from a single-parent pool. Shi (1993), in his classic paper about the comparative analysis of several similarity coefficients, did not test the reliability of Raup-Crick Coefficients because, as it was commented by Cleal (2008b), the laborious computing tasks required at that time made its practical use difficult. In the presentday, modern software packages enable such calculations to be done in seconds, and now Raup-Crick Coefficients are a very powerful tool for palaeobotanical and palaeobiological analyses, like that attempted here.

In light of these views, this study has been performed based on the Jaccard and Raup-Crick Coefficients as a comparative approach. Initially, several clustering methods including Unweighted Pair-Group Mean Average (UPGMA), Single Linkage Clustering Algorithm (SLCA) and Ward's Method were employed. The Ward's method was used to contrast the cluster results based on similarity measures and to avoid possible methodological bias due to this algorithm is founded on the Euclidean distance (Hammer \& Harper, 2006); nevertheless, preliminary results revealed a strong variation in the cophenetic correlation values between the several algorithms performed (Table 2). In this paper, similarity coefficients were clustered using the UPGMA algorithm, because this clustering method showed the best cophenetic correlation values independently of the similarity measures used (Table 2). The results are illustrated using the traditional type of dendrograms. Clustering was stratigraphically constrained, and only stratigraphically-adjacent time units were clustered during the agglomerative procedure. Although this might impose a preordained pattern on the output, according to the literature, bootstrapping in fact reveals that a stratigraphically-constrained cluster analysis provides a more robust reflection of the data structure than unconstrained clustering. The raw similarity data of the several clusters are available from the supporting information (Tables 3 and 4). These were all performed using the PAST software package (Hammer et al., 2001).

Table 2. Cophenetic correlation values $(r)$ of the several algorithms employed.

\begin{tabular}{cccc}
\hline Algorithm & Jaccard & Raup-Crick & $\begin{array}{c}\text { Euclidean } \\
\text { distance }\end{array}$ \\
\hline Unweighted Pair-Group Mean Average & 0.8911 & 0.8107 & \\
$\begin{array}{c}\text { Single Linkage Clustering Algorithm } \\
\text { Ward's Method }\end{array}$ & 0.8676 & 0.7556 & \\
\hline
\end{tabular}

Table 3. Similarity matrix based on the Jaccard Coefficients.

\begin{tabular}{ccccccccc}
\hline US & LD & MD & UD & LC & UC & LP & UP & LT \\
\hline US 1.0000 & & & & & & & \\
LD 0.5000 & 1.0000 & & & & & & \\
MD 0.1539 & 0.2857 & 1.0000 & & & & & & \\
UD 0.1053 & 0.1429 & 0.5790 & 1.0000 & & & & & \\
LC 0.0000 & 0.0278 & 0.1944 & 0.2564 & 1.0000 & & & & \\
UC 0.0000 & 0.0196 & 0.0741 & 0.1035 & 0.3750 & 1.0000 & & & \\
LP 0.0000 & 0.0270 & 0.0476 & 0.0870 & 0.2353 & 0.5294 & 1.0000 & & \\
UP 0.0000 & 0.0000 & 0.0244 & 0.0667 & 0.1091 & 0.2667 & 0.5122 & 1.0000 & \\
LT 0.0000 & 0.0000 & 0.0370 & 0.0625 & 0.0444 & 0.0877 & 0.1429 & 0.2778 & 1.0000
\end{tabular}

Table 4. Similarity matrix based on the Raup-Crick Coefficients.

\begin{tabular}{ccccccccc}
\hline US & LD & MD & UD & LC & UC & LP & UP & LT \\
\hline US 1.0000 & & & & & & & \\
LD 1.0000 & 1.0000 & & & & & & & \\
MD 0.9625 & 0.9925 & 1.0000 & & & & & &
\end{tabular}

UD 0.89000 .89251 .00001 .0000

LC 0.09250 .08000 .83000 .87001 .0000

UC 0.03250 .02000 .03500 .00000 .80501 .0000

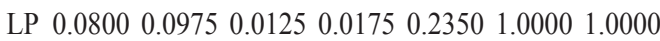

UP $0.0850 \quad 0.02000 .00250 .00500 .00000 .15501 .00001 .0000$

$\begin{array}{lllllllllll}\text { LT } & 0.2075 & 0.1125 & 0.1225 & 0.0900 & 0.0025 & 0.0075 & 0.2525 & 0.9600 & 1.0000\end{array}$

\section{RESULTS AND DISCUSSION}

The multivariate analysis based on the similarity and clustering methods appears in figure 1. In general terms, the results based on the Jaccard Coefficients show a pattern in which similarity decreases non proportionally toward more modern intervals (Table 3 ). The similarity measures demonstrate how the chronological consecutive intervals of one same period show lower similarity values than the intervals of different periods. This fact can be observed, for example, in the cluster formed by the Pennsylvanian and the Early Permian. In this cluster, the taxonomic composition of the Pennsylvanian is more analogous with the Permian flora than with the Mississippian (Fig. 1a).

On the other hand and irrespectively of the chosen similarity coefficient, the data representation does not reveal a major difference from the cluster groups. Nevertheless, the Raup-Crick Coefficients better adjust the clustered groups. Only a few changes can be observed at the end of the Palaeozoic where the UPGMA algorithm reveals a major affinity between the Late Permian and the Early Triassic when the Raup-Crick Coefficients are used. The cluster results obtained using the Raup-Crick Coefficients 
clearly demonstrate that there are four groups of time units which represent robust clusters (Fig. 1b). These groups are in accordance with the different interpretations of the

\section{a) Jaccard Similarity Coefficients}

\section{$\begin{array}{lllllllllll}0 & 0.1 & 0.2 & 0.3 & 0.4 & 0.5 & 0.6 & 0.7 & 0.8 & 0.9 & 1\end{array}$}



\section{b) Raup-Crick Similarity Coefficients}

\section{\begin{tabular}{llllllllll}
0.1 & 0.2 & 0.3 & 0.4 & 0.5 & 0.6 & 0.7 & 0.8 & 0.9 & 1 \\
\hline
\end{tabular}}

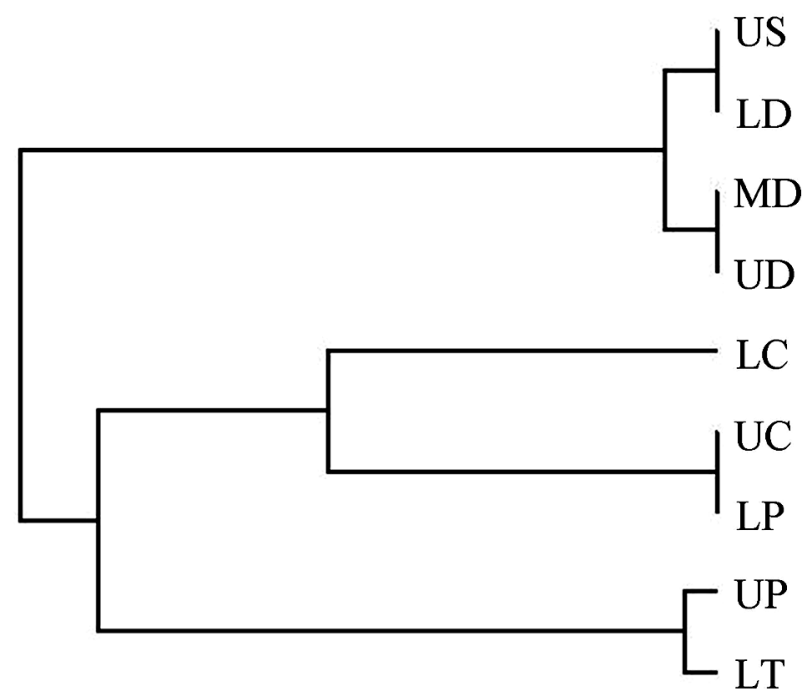

Figure 1. Cluster analyses of the Palaeozoic plant fossil record analyzed. Details of the analytical method used are given in the text (see Material and Methods). a, Cluster analysis based on the Jaccard Coefficients. Raw data is given in Table 3. b, Cluster analysis based on the Raup-Crick Coefficients. Raw data is given in Table 4. plant fossils cited in the literature and they represent an easy, global vision of the Palaeozoic plant fossil record.

The first group of the dendrogram corresponds to the time units of the Late Silurian and the Early Devonian, and it is during this interval that the first origination and radiation of vascular land plants take place. This cluster contains the early evolutionary trends of vascular plants, which constitutes a special time in plant life history. Some of these taxa, rhyniophytes for instance, are characterized by terminal sporangia and dichotomous branching (Cleal \& Thomas, 1994; Roth-Nebelsick et al., 2000), whereas others, like zosterophylls and trimerophytes, have sporangia that aggregate into terminal spikes (Edwards, 1969; Banks \& Niklas, 1989) and a trifurcating branching pattern (Niklas \& Banks, 1985; Rothwell, 1999), respectively. Previous works (Gensel \& Andrews, 1984; McGhee, 1996; Godderis \& Joachimski, 2004; Cascales-Miñana \& Ruiz-Sánchez, 2009) reveal, as others in the literature have, that the plant fossil record which included these taxa groups considerably reduced in the Middle Devonian until these taxa totally disappeared at the end of the Devonian. Among other considerations, this fact could explain the robustness of this cluster.

The second cluster corresponds to the Middle and the Late Devonian. This section on the geologic time scale is a very important episode of plant life history, and is characterized not only by the increased size of the vascular forms of lycophytes which developed into the arborescent habit (Gensel \& Berry, 2001), but also by the origin and consolidation of the progymnosperm groups (Gensel \& Andrews, 1984; Cleal \& Thomas, 1999). Progymnosperms have an important effect on plant evolution because they develop large, secondary-thickened, gymnosperm-like axes which allow many of them to reach arborescent proportions (Fairon-Demaret \& Leponce, 2001; Scheckler \& Galtier, 2003). Note, however, that their free-spore reproductive habit was pteridophytic (Marshall, 1996). These plants were the first true trees on the Earth, and they represent the phylogenetic intermediates between the early vascular pteridophytes and seed plants. All these evolutionary innovations emphasize the particular character of this cluster.

Interestingly, the Mississippian is a time unit whose taxonomic composition is not shared with the other time units analysed as this interval is only linked to time intervals with very low coefficient values (Fig. 1). This fact could be explained as result of the extinction processes and the evolutionary dynamics, that is, processes which would lead to many taxa of the Mississippian not being recorded in the subsequent intervals. This context can be observed in the similarity measures based on the Jaccard and Raup-Crick Coefficients (Tables 3 and 4). Among other interpretations, the results suggest that the taxa which originated in the Devonian radiation underwent a fast diversification process. Nevertheless, not all the groups achieved the same evolutionary success in terms of prolonged dura- 
tion (Rothwell, 1996; Cascales-Miñana \& Ruiz-Sánchez, 2008 b), but generated a taxonomic turnover process that is reflected in the similarity and clustering methods in terms of Mississippian flora.

The fourth cluster is formed by the Pennsylvanian and the Early Permian (Fig. 1). The vast majority of the diversity of the exclusive vascular plant groups, for example some types of seed ferns or pteridosperms, date back to the end of the Carboniferous. The literature offers considerable evidence that a palaeoclimatic change was the main cause of extinction (Phillips \& Peppers, 1984; Cecil, 1990; Kosanke \& Cecil, 1996). The results of the similarity and clustering methods mark a sloped change between the Mississippian and the Pennsylvanian. The clustering methods support several published ideas about this topic (Phillips \& Peppers, 1984; Phillips \& Cecil, 1985; Phillips et al., 1985; DiMichele et al., 1987; DiMichele \& Phillips, 2002; Shute \& Cleal, 2002) and offer a plausible explanation of this observation: it is likely that the two humid periods documented in the Carboniferous would not have been of equal magnitude in water regime terms, and such was the extent of this scenario that a gradual drying of habitats would have taken place. This could be one of the main causes behind both the turnover of the structural plans and the reduced plant fossil record representation of the arborescent forms of Lycophytes.

The last cluster, made up of the Late Permian and the Early Triassic, and performed with the Raup-Crick Coefficients, does not correlate in the dendrogram based on the Jaccard Coefficients. Nevertheless, both coefficients are in agreement with the differences between the two Permian time units. The Permian mass extinction event is probably the most significant of life history and probably affected virtually all marine invertebrates (Sepkoski, 1988; Benton, 1995). Nevertheless, previous studies (Cascales-Miñana \& Ruiz-Sánchez, 2007, 2008a, 2009) only reflect a gradual reduction of diversity from the end of the Mississippian, which is based on the change of the vegetation mainly dominated by lycophytes, sphenophytes, filicophytes and pteridosperms to other forms of vegetation dominated by cycads, ginkgos and conifers in the Palaeozoic-Mesozoic transition (Knoll, 1984; Knoll \& Niklas, 1987; Jablonski \& Sepkoski, 1996; Willis \& McElwain, 2002).

All these considerations reveal that the saltational changes illustrated by the similarity measures, irrespectively of the chosen coefficients, are a result of the differential taxonomic composition among the time units. This fact could be explained by either the appearance of evolutionary innovations or the changes brought about by extinctions together with the geologic constraints associated with these methods. Thus, together with the rock-record bias, the evolutionary innovations and the ecological context are some of the factors that condition the taxonomic composition. Nevertheless, extinction events may have affected the several lineages unequally. In my opinion, the taxonomic changes caused by these processes would be reflected in the measures of similarity among the intervals both before and after these events. Based on the Jaccard Coefficients, this fact is reflected as important variations of similarity among the time units in the Devonian-Carboniferous transition (Table 3). The effects of the extinction events can also be observed in the Mississippian-Pennsylvanian transition when a considerable number of taxa extinguished. It is possibly for these reasons that the Carboniferous time unit does not appear enclosed in a single cluster. On the other hand, the cluster formed by the primitive flora at the end of the Silurian and in the Early Devonian is quite far from the rest of the intervals (Fig. 1a), but it is also important to note that, this flora is very close to the cluster formed by the Middle and Late Devonian (Fig. 1b). This observation is probably related to the plant fossil record composition and to the declivity of the primitive structural plans of vascular plants, as previously mentioned. Finally, the special case of Mississippian flora, where many taxa are not recorded in the subsequent intervals, emphasizes the fact that the similarity based on Jaccard Coefficients among the several time units obtains its minimum value when the last taxon of the oldest interval extinguishes.

\section{CONCLUDING REMARKS}

This study uses cluster analyses with two similarity measures, on the one hand, the descriptive binary similarity measure of the Jaccard's index and the other hand, the probabilistic similarity measure of Raup-Crick, to show the palaeofloristic composition of the Palaeozoic fossil record from a cluster viewpoint. It is universally accepted that the palaeofloristic structure has not remained constant through Palaeozoic times. Accordingly, the cluster analyses presented herein reveal significant discontinuities in terms of taxonomic composition, especially between Mississippian flora and the several floras of the subsequent time units. Nevertheless, a special mention requires the deep disruption observed, with both coefficients, between the Early and Middle Devonian.

Previous studies (Cleal \& Shute, 1995; Thomas, 2007) have used cluster analyses with Jaccard Coefficients. The present study has confirmed that cluster analysis is a powerful tool for such work, but the Raup-Crick Similarity Coefficients may provide a better pattern resolution within the data. Along these lines, although the cluster analyses were performed with both similarity measures and they essentially provide similar results, the Raup-Crick Coefficients clearly have the potential for providing more robust results, whereas the consequence of the extinction processes appears to be better reflected in the Jaccard Coefficients-based analysis.

This study provides new evidence of the importance of using more than one type of similarity coefficients and comparing the results with both measures to obtain a bet- 
ter interpretation of the fossil record data. On the other hand, due to the controversial character of taxonomic data, which present an inevitable subjective basis, and the nature of the taxonomic process that are in constant revision, in concordance with recent ideas about the influence of the taxonomy in the palaeobiological works (Valentine \& May, 1996; Robeck et al., 2000; Adrain \& Westrop, 2003; Alroy, 2003; Lane et al., 2005), this type of approaches would need be re-examined in the future in agreement with new hierarchic systems taking into account new discoveries and new taxonomic classifications.

Finally, the results presented here demonstrate that the similarity measures are an excellent indicator of the processes that modify the taxonomic composition of the plant record. Furthermore, the results also show that analysing the plant fossil record with similarity and clustering methods proves a powerful tool to interpret plant life history from a synthetic viewpoint.

\section{SUPPORTING INFORMATION}

Table S1. Families and the main predominant types of fossil compiled to codify the binary matrix of the analysis. Families appear in alphabetic order. For more details, see the consulted sources in Material and Methods.

\section{ACKGNOWLEDGMENTS}

I would like to specially thank Christopher J. Cleal (Department of Biodiversity and Systematic Biology, National Museum of Wales) for his important comments about the similarity coefficients and for supplying me with the necessary methodological information about statistical processing. I am very pleased to be able to express my sincere thanks to Jose B. Diez (Department of Marine Geosciences and Land Use Planning, University of Vigo) for his detailed revision of the manuscript and his evolutionary reflections. I am also grateful to Hector Botella (Department of Geology, University of Valencia) for his comprehensive and detailed remarks about the philosophy of the clustering methods. Finally, I thank Miguel Guara (Department of Botany, University of Valencia) for his comments and reflections about the similarity methods. This work has been partially supported by the FPU Research Fellowship from the Spanish Ministry of Education and Science. Dedicated to my wife.

\section{REFERENCES}

Adrain, J.M. \& Westrop, S.R. 2003. Paleobiodiversity: we need new data. Paleobiology, 29, 22-25.

Alroy, J. 2003. Global databases will yield reliable measures of global biodiversity. Paleobiology, 29, 26-29.

Allen, K.C. \& Marshall, J.E.A. 1986. Svalbardia and the 'corduroy' plant from the Devonian of the Shetland Islands, Scotland. Special Papers in Palaeontology, 35, 7-20.
Anderson, J.M. \& Anderson, H.M. 1985. Palaeoflora of Southern Africa. Prodromus of South Africa Megafloras Devonian to Lower Cretaceous. Balkema, Rotterdam, 423 pp.

Archangelsky, S. \& Cúneo, R. 1987. Ferugliocladaceae, a new conifer family from the Permian of Gondwana. Review of Palaeobotany and Palynology, 51, 3-30.

Asama, K. 1962. Evolution of Shansi flora and origin of simple leaf. Science Reports, Tohoku University, 2nd Series (Geology) Special Volume, 5, 247-274.

Ash, S.R. 1969. Ferns from the Chinle Formation (Upper Triassic) in the Fort Wingate area, New Mexico. United States Geological Survey Professional Paper, 613, 1-52.

Banks, H.P. \& Niklas, K.J. 1989. A reevaluation of the Zosterophyllophytina with comments on the origin of Lycopods. American Journal of Botany, 77, 274-283.

Barnard, P.D.W. 1959. On Eosperma oxroadense gen. et sp. nov. a Lower Carboniferous seed from East Lothian. Annals of Botany, 90, 284-296.

Barnard, P.D.W. \& Long, A.G. 1975. Triradioxylon a new genus of Lower Carboniferous petrified stems and petioles together with a review of the classification of early Pteridophytina. Transactions of the Royal Society of Edinburgh, 69, 231-250.

Barthel, M. 1976. Die Rotliegendflora Sachsens. Abhandlungen des Staatlichen Museums für Mineralogie und Geologie zu Dresden, 24, 1-190.

Benton, M.J. 1993. The Fossil Record 2. Chapman and Hall, London, $845 \mathrm{pp}$.

Benton, M.J. 1995. Diversification and extinction in the history of life. Science, 268 (5207), 52-58.

Bertrand, C.E. 1895. Sur une nouvelle centradesmide de 1'Époque houillère. Association française avancement science, Comptes rendus 23e session, 588-593.

Bertrand, P. 1913. Étude du stipe de l'Asteropteris noveboracensis. Compte rendu 12e Congrès géologie du Canada, 909-924.

Bonamo, P.M. \& Banks, H.P. 1967. Tetraxylopteris schmidtii: its fertile parts and its relationship within the Aneuphytales. American Journal of Botany, 54, 755-768.

Bouroz, A. \& Doubinger, J. 1977. Report on the StephanianAutunian boundary and on the contents of Upper Stephanian and Autunian in their stratotypes. In: Symposium on Carboniferous Stratigraphy (Eds. V. Holub \& R.H. Wagner). Geological Survey, Prague, 147-169 pp.

Brack-Hanes, S.D. 1981. On a lycopsid cone with winged spores. Botanical Gazette, 142, 294-304.

Brousmiche, C. 1983. Les fougères sphénoptéridiennes du Bassin Houiller Sarro-Lorrain. Société Géologique du Nord Publication, 10, 1-480.

Carpentier, A. 1935. Étude paléobotanique sur le groupe de la Sakoa et le groupe de la Sakmena (Madagascar). Annales géologiques du Service des Mines, Madagascar, 5, 7-32.

Cascales-Miñana, B. \& Ruiz-Sánchez, F.J. 2007. Distribución de tasas evolutivas en plantas vasculares entre el Silúrico y el Pleistoceno. In: Cantera Paleontológica (Eds. O. Cambra-Moo, C. Martínez-Pérez, B. Chamero, F. Escaso, S. de Esteban Trivigno \& J. Marugán-Lobón). Diputación de Cuenca, Cuenca, 99-109. 
Cascales-Miñana, B. \& Ruiz-Sánchez, F.J. 2008a. Medida del éxito evolutivo de las floras del Paleozoico basada en técnicas de clasificación numérica. In: Palaeontologica Nova (Eds. J. Esteve \& G. Meléndez). Universidad de Zaragoza, Zaragoza, 151-163.

Cascales-Miñana, B. \& Ruiz-Sánchez, F.J. 2008b. Patrones paleobiológicos y éxito evolutivo de las floras del $\mathrm{Pa}$ leozoico. In: XXIV Jornadas de la Sociedad Española de Paleontología (Eds. J.I. Ruiz-Omeñaca, L. Piñuela \& J.C. García-Ramos). Museo del Jurásico de Asturias, Colunga, 19-20.

Cascales-Miñana, B. \& Ruiz-Sánchez, F.J. 2009. Taxonomic survivorship curves and plant fossil record. In: XXV Jornadas de la Sociedad Española de Paleontología (Eds. P. Palmqvist \& J.A. Pérez-Claros). Universidad de Málaga, Ronda, 56-60.

Cascales-Miñana, B., Muñoz-Bertomeu, J., Ros, R. \& Segura, $\mathrm{J}$. in press. Trends and patterns in the evolution of vascular plants: macroevolutionary implications of a multilevel taxonomic analysis. Lethaia.

Cecil, C.B. 1990. Paleoclimate controls on stratigraphic repetition of chemical and siliciclastic rocks. Geology, 18, 533-536.

Chaloner, W.G. 1953. On the megaspore of four species of Lepidostrobus. Annals of Botany, 17, 264-273.

Chaloner, W.G. 1958. Polysporia mirabilis Newberry, a fossil lycopod cone. Journal of Paleontology, 32, 199-209.

Chaloner, W.G. 1968. The cone of Cyclostigma kiltorkense Haughton, from the Upper Devonian of Ireland. Botanical Journal of the Linnean Society, 61, 25-36.

Cichan, M.A. \& Taylor, T.N. 1982. Structurally preserved plants from southeastern Kentucky: Stauropteris biseriata sp. nov. American Journal of Botany, 69, 1491-1496.

Cleal, C.J. 1993a. Plants. 43. Pteridophyta. In: The Fossil Record 2 (Ed. M.J. Benton). Chapman and Hall, London, 779-794.

Cleal, C.J. 1993b. Plants. 44. Gymnospermophyta. In: The Fossil Record 2 (Ed. M.J. Benton). Chapman and Hall, London, 795-808.

Cleal, C.J. 2008a. Palaeofloristics of Middle Pennsylvanian lyginopteridaleans in Variscan Euramerica. Palaeogeography, Palaeoclimatology, Palaeoecology, 261, 1-14.

Cleal, C.J. 2008b. Palaeofloristics of Middle Pennsylvanian medullosaleans in Variscan Euramerica. Palaeogeography, Palaeoclimatology, Palaeoecology, 268, 164-180.

Cleal, C.J. \& Shute, C.H. 1995. A synopsis of neuropteroid foliage from the Carboniferous and Lower Permian of Europe. Bulletin of the British Museum (Natural History), Geology Series, 51, 1-52.

Cleal, C.J. \& Thomas, B.A. 1994. Palaeozoic palaeobotany of Great Britain. Chapman and Hall, London, 312 pp.

Cleal, C.J. \& Thomas, B.A. 1999. Plant Fossils: the history of land vegetation. The Boydell Press, Woodbridge, 128 pp.

Clement-Westerhof, J.A. 1987. Aspects of Permian palaeobotany and palynology. VII. The Majonicaceae, a new family of Late Permian conifers. Review of Palaeobotany and Palynology, 52, 375-402.

Clement-Westerhof, J.A. 1988. Morphology and phylogeny of Paleozoic conifers. In: Origin and Evolution of Gym- nosperms (Ed. C.B. Beck). Columbia University Press, New York, 298-337.

Coiffard, C., Gomez, B., Nel, A., Kvaek, J., Neraudeau, D. \& Thévenard, F. 2008. Application of the Wagner's Parsimony Method in fossil plant assemblages from the Cretaceous of Europe. Review of Palaeobotany and Palynology, 148, 1-12.

Costeur, L. \& Legendre, S. 2008. Spatial and temporal variation in European Neogene large mammals diversity. Palaeogeography, Palaeoclimatology, Palaeoecology, 261, 127-144.

Costeur, L., Legendre, L. \& Escarguel, G. 2004. European large mammals palaeobiogeography and biodiversity from the Early Miocene to the Mid-Pliocene. Palaeogeographic and climatic impacts. Revue de Paléobiologie, 9, 99-109.

Cridland, A.A. \& Morris, J.E. 1963. Taeniopteris, Walchia and Dichophyllum in the Pennsylvanian System of Kansas. University of Kansas Science Bulletin, 44, 71-85.

Croft, W.N. \& Lang, W.H. 1942. The Lower Devonian flora of the Senni Beds of Monmouthshire and Breconshire. Philosophical Transactions of the Royal Society of London $B, 231,131-164$.

Crookall, R. 1966. Fossil plants of the Carboniferous rocks of Great Britain [Second section]. Part 4. Memoirs of the Geological Survey of Great Britain, Palaeontology, 4, 355-572.

Delevoryas, T. \& Gould, R.E. 1971. An unusual fossil fructification from the Jurassic of Oaxaca, Mexico. American Journal of Botany, 58, 616-620.

Delevoryas, T. \& Person, C.P. 1975. Mexiglossa varia gen. et sp. nov., a new genus of glossopterid leaves from the Jurassic of Oaxaca, Mexico. Palaeontographica Abteilung $B$, 154, 114-120.

Digby, P.G.N. \& Kempton, R.A. 1987. Multivariate analysis of ecological communities. Chapman and Hall, London, 206 pp.

DiMichele, W.A. \& Bateman, R.M. 1992. Diaphorodendraceae, fam. nov. (Lycopsida: Carboniferous): systematics and evolutionary relationships of Diaphorodendron and Synchysidendron, gen. nov. American Journal of Botany, 79, 605-617.

DiMichele, W.A. \& Phillips, T.L. 2002. The ecology of Paleozoic ferns. Review of Palaeobotany and Palynology, 119, 143-159.

DiMichele, W.A., Phillips, T.J. \& Olmstead, R.G. 1987. Opportunistic evolution: Abiotic environmental stress and the fossil record of plants. Review of Palaeobotany and Palynology, 50, 151-187.

Dimitrova, T.K.H. \& Cleal, C.J. 2007. Palynological evidence for late Westphalian-early Stephanian vegetation change in the Dobrudzha Coalfield, NE Bulgaria. Geological Magazine, 144, 513-524.

Edwards, D. 1969. Zosterophyllum from Lower Old Red Sandstone of South Wales. New Phytologist, 68, 923-931.

Edwards, D. 1972. A Zosterophyllum fructification from the Lower Old Red Sandstone of Scotland. Review of Palaeobotany and Palynology, 14, 77-83.

Edwards, D. 1975. Some observations on the fertile parts of Zosterophyllum myretonianum Penhallow from the Lower 
Old Red Sandstone of Scotland. Transactions of the Royal Society of Edinburgh, 69, 251-265.

Edwards, D. \& Richardson, J.B. 2004. Silurian and Lower Devonian plant assemblages from the Anglo-Welsh Basin: a palaeobotanical and palynological synthesis. Geological Journal, 39, 375-402.

Edwards, D., Davies, K.L. \& Axe, L.M. 1992. A vascular conducting strand in the early land plan Cooksonia. $\mathrm{Na}$ ture, 357, 683-685.

Eggert, D.A. \& Delevoryas, T. 1967. Studies of Paleozoic ferns: Sermaya gen. nov. and its bearing on filicalean evolution in the Paleozoic. Palaeontographica Abteilung $B, \mathbf{1 2 0}, 169-180$.

El-Saadway, W. \& Lacey, W.S. 1979. The sporangia of Horneophyton lignieri (Kidston and Lang) Barghoorn and Darrah. Review of Palaeobotany and Palynology, 28, 137-144.

Erwin, D.M. \& Rothwell, G.W. 1989. Gillespiea randolphensis gen. et sp. nov. (Stauropteridales), from the Upper Devonian of West Virginia. Canadian Journal of Botany, 67, 3063-3077.

Escapa, I.H. \& Cúneo, N.R. 2006. First record of Neocalamites (Halle) Vladimirovicz in the Permian of Gondwana. Ameghiniana, 43, 85-92.

Fairon-Demaret, M. 1977. A new lycophyte cone from the Upper Devonian of Belgium. Palaeontographica Abteilung $B, \mathbf{1 6 2}, 51-63$.

Fairon-Demaret, M. \& Leponce, I. 2001. Leaf dimorphism in Archaeopteris roemeriana (Progymnosperm): further early fossil evidence of shoot dorsiventrality. American Journal of Botany, 88, 729-735.

Feng, S., Chen, G. \& Xi, Y. 1977. Plants. Fossil Atlas of Central-South China II. Geological Publishing House, Institute of Geological Sciences, Beijing, 662-674 [in Chinese].

Figueirido, B., Palmqvist, P. \& Perez-Claros, J.A. 2009. Ecomorphological correlates of craniodental variation in bears and paleobiological implications for extinct taxa: an approach based on geometric morphometrics. Journal of Zoology, 277, 70-80.

Foote, M. 1997. Estimating taxonomic durations and preservation probability. Paleobiology, 23, 278-300.

Frobisch, J. 2009. Composition and similarity of global anomodont-bearing tetrapod faunas. Earth-Science Reviews, 95, 119-157.

Galtier, J. 1967. Les sporanges de Botryopteris antiqua Kidston. Compte rendu des séances de l'Académie des Sciences, 265, 897-900.

Galtier, J. 1971. La fructification de Botryopteris forensis Renault (Coenoptéridales de Stéphanien Français): précisions sur les sporanges et les spores. Naturalia monspeliana, Série Botanique, 22, 145-155.

Galtier, J. 1978. Précisions sur Zygopteris lacattei and Botryopteris dubius, fougères très rares de l'Autunien d'Autun. Bulletin de la Societé d'Histoire Naturelle d'Autun, 88, 17-25.

Galtier, J. \& Rowe, N.P. 1989. A primitive seed-like structure and its implications from early gymnosperm evolution. Nature, 340, 225-227.
Galtier, J. \& Scott, A.C. 1979. Studies of Palaeozoic ferns: on the genus Corynepteris. A redescription of the type and some other European species. Palaeontographica Abteilung B, 170, 81-125.

Gensel, P.G. \& Andrews, H.N. 1984. Plant life in the Devonian. Praeger, New York, 381 pp.

Gensel, P.G. \& Berry, C.M. 2001. Early lycophyte evolution. American Fern Journal, 91, 74-98.

Gerrienne, P. 1983. Les plantes emsiennes de Marchin (Vallée du Hoyoux, Belgique). Annales de la Societé Géologique de Belgique, 106, 19-35.

Godderis, Y. \& Joachimski, M.M. 2004. Global change in the Late Devonian: modelling the Frasnian-Famennian short-term carbon isotope excursions. Palaeogeography, Palaeoclimatology, Palaeoecology, 202, 309-329.

Good, C.W. 1981. A petrified fern sporangium from the British Carboniferous. Palaeontology, 24, 483-492.

Gordon, W.T. 1910. On a new species of Physostoma from the Lower Carboniferous rocks of Pettycur (Fife). Proceedings of the Cambridge Philosophical Society, 15, 395-397.

Gorelova, S.G., Menshikova, L.V. \& Khalfin, L.L. 1973. Phytostratigraphy and plant taxonomy in the Upper Palaeozoic coal-bearing deposits of the Kuznetsk Basin. Trudy Sibirskogo Nauchno-Issledovatel'skogo, Geologii, Geofiziki i Mineral'nogo, 140, 1-169 [in Russian].

Gothan, W. 1931. Die Steinkohlenflora der westlichen paralischen Carbonreviere Deutschlands. 2. Arbeiten aus dem Insitut für Paläobotanik und Petrographie der Brennsteine, 1, 49-96.

Gradstein, F.M. \& Ogg, J.G. 2004. Geologic time scale 2004 - Why, how, and where next! Lethaia, 37, 175-181.

Grauvogel-Stamm, L. 1978. La flore du grès à Voltzia (Buntsandstein supérieur) des Vosges du Nord (France). Morphologie, anatomie, interprétations phylogéniques et paléogéographique. Université L. Pasteur de Strasbourg, Insitute Géologique, Mémoires, 50, 1-225.

Grauvogel-Stamm, L. \& Duringer, P. 1983. Annalepsis zeilleri Fliche 1910 emend., un organe reproducteur de Lycophyte de la Lettenkohle de 1'Est de la France. Geologische Rundschau, 72, 23-51.

Halle, T.G. 1927. Palaeozoic plants from central Shansi. Palaeontologica Sinica, Series A, 2 (1), 1-316.

Halle, T.G. 1932. On the seeds of the pteridosperm Emplectopteris triangularis. Geological Society of China Bulletin, 11, 301-306.

Hammer, O. \& Harper, D.A.T. 2006. Paleontological Data Analysis. Blackwell Publishing, Oxford, 368 pp.

Hammer, O., Harper, D.A.T. \& Ryan, P.D. 2001. Past: Paleontological Statistics Software Package for Education and Data Analysis. Palaeontologia Electronica, 4, 9 pp.

Hill, C.R. \& Camus, J.M. 1986. Evolutionary cladistics of marattialean ferns. Bulletin of the British Museum (Natural History) Botany, 14, 219-300.

Hill, C.R., Wagner, R.H. \& El-Khayal, A.A. 1985. Qasimia gen. nov., an early Marattia-like fern from the Permian of Saudi Arabia. Scripta Geologica, 79, 1-50.

Hilton, J. \& Cleal, C.J. 2007. The relationship between Euramerican and Cathaysian tropical floras in the Late $\mathrm{Pa}-$ 
laeozoic: Palaeobiogeographical and palaeogeographical implications. Earth-Science Reviews, 85, 85-116.

Hirmer, M. 1941. Noeggerathia, neuendeckte verwandte Formen und ihre Stellung im System der Farne. Biologia Generalis, 15, 134-171.

Holmes, J.C. 1981. The Carboniferous fern Psalixochlaena cylindrica as found in Westphalian. A coal balls from England. Part II. The frond and fertile parts. Palaeontographica Abteilung B, 176, 147-173.

Hueber, F.M. 1971. Sawdonia ornata: a new name for Psilophyton princeps var. ornata. Taxon, 16, 641-642.

Hueber, F.M. 1972. Rebuchia ovata, its vegetative morphology and classification with Zosterophyllophytina. Review of Palaeobotany and Palynology, 14, 113-127.

Ischenko, T.A. 1965. Devonian Floras of Greater Donbass. Akademia Nauk, Kiev, 300 pp. [in Russian]

Jablonski, D. \& Sepkoski, J.J. 1996. Paleobiology, community ecology, and scales of ecological pattern. Ecology, 77, 1367-1378.

Josten, K.H. 1983. Die fossilen Floren im Namur des Ruhrkarbons. Fortschritte in der Geologie von Rheinland und Westfalen, 31, 1-327.

Jud, N.A., Rothwell, G.W. \& Stockey, R.A. 2008. Todea from the Lower Cretaceous of western North America: implications for the phylogeny, systematics, and evolution of modern Osmundaceae. American Journal of Botany, 95, 330-339.

Kaspar, A.E., Gensel, P.G. \& Forbes, W.H. 1988. Plant paleontology in the State of Maine - a review. Maine Geological Survey. Studies in Maine Geology, 1, 109-128.

Kerp, J.H.F. 1984. Aspects of Permian palaeobotany and palynology. V. On the nature os Asterophyllites demuasii Zeiller, its correlation with Calamites gigas Brongniart and the problem concerning its sterile foliage. Review of Palaeobotany and Palynology, 41, 301-317.

Kerp, J.H.F. \& Fichter, J. 1985. Die Makrofloren des saarpfälzischen Rotliegenden (Ober-Karbon-Unter Perm; SWDeutchland). Mainzer geowissenschaftliche Mitteilungen, 14, 159-286.

Kerp, H. \& Naugolnykh, S.V. 1996. Aspects of Permian palaeobotany and palynology. XV. On the oldest known peltasperms with radially symmetrical ovuliferous discs from the Kungurian (uppermost Lower Permian) of the Fore-Urals (Russia). Review of Palaeobotany and Palynology, 91, 35-62.

Kidston, R. 1911. Les végéteux houillers recueillis dans le Hinaut Belge. Mémoires du Musée Royal d'Histoire Naturelle de Belgique, 4, 1-282.

Kidston, R. \& Gwynne-Vaughan, D.T. 1908a. On the fossil Osmundaceae. Part II. Transactions of the Royal Society of Edinburgh, 46, 213-232.

Kidston, R. \& Gwynne-Vaughan, D.T. 1908b. On the fossil Osmundaceae. Part III. Transactions of the Royal Society of Edinburgh, 46, 651-667.

Kimura, T. \& Okubo, A. 1985. Nilssonia dictyophylla sp. nov. from the Lower Cretaceous Choshi Group, in the Outer Zone of Japan. Proceedings of the Japan Academy. Series B: Physical and Biological Sciences, 61, 430-432.
Knoll, A.H. 1984. Patterns of extinction in the fossil record of vascular plants. In: Extinctions (Ed. M.H. Nitecki). University of Chicago Press, Chicago, 21-68.

Knoll, A.H. \& Niklas, K.J. 1987. Adaptation, plant evolution, and the fossil record. Review of Palaeobotany and Palynology, 50, 127-149.

Kon'no, E. 1962. Some species of Neocalamites and Equisetites in Japan and Korea. Science Reports of the Tohoku University Sendai, 2nd Series Geology, 5, 21-27.

Kon'no, E. 1973. New species of Pleuromeia and Neocalamites from the Upper Scythian beds in the Kitakami Massif, Japan - with a brief note on some equisetacean plants from the Upper Permian bed in the Kitakami Massif. Science Reports, Tohoku University, 2nd Series Geology, 43, 99-115.

Kon'no, E., Asama, K. \& Rajah, S.S. 1971. The later Permian Lingin flora from the Gunong Area, Johore, Malaysia. In: Geology and Palaeontology of Southeast Asia (Eds. T. Kobayashi \& O. Toriyama). Tokyo University Press, Tokyo, 1-86.

Kosanke, R.M. \& Cecil, C.B. 1996. Late Pennsylvanian climate changes and palynomorph extinctions. Review of Palaeobotany and Palynology, 90, 113-140.

Kovach, W.L. 1988. Multivariate methods of analyzing palaeoecological data. In: Methods and applications of plant palaeoecology. Special Publication (Eds. W.A. DiMichele \& S.L. Wing). The Paleontological Society, Tennessee, 72-104.

Kramer, A. \& Konigsberg, L.W. 1999. Recognizing species diversity among large-bodied hominoids: a simulation test using missing data finite mixture analysis. Journal of Human Evolution, 36, 409-421.

Kräusel, R. \& Weyland, H. 1937. Pflanzenreste aus dem Devon. X. Zwei Pflanzenfunde im Oberdevon der Eifel. Senckenbergiana, 19, 338-355.

Kubart, B. 1910. Untersuchungen über die Flora des OstrauKarwiner Kohlenbeckens. I. Die Spore von Spencerites membranaceous nov. spec. Denkschrift der Akademie Wissenschaft in Wien, Mathematisch-Naturwissenschaft Klasse, 85, 83-89.

Kvaček, J., Dašková, J. \& Renáta, P. 2006. A new schizaeaceous fern, Schizaeopsis ekrtii sp. nov., and its in situ spores from the Upper Cretaceous (Cenomanian) of the Czech Republic. Review of Palaeobotany and Palynology, 140, 51-60.

Lane, A. \& Benton, M.J. 2003. Taxonomic level as a determinant of the shape of the phanerozoic marine biodiversity curve. American Naturalist, 162, 265-276.

Lane, A., Janis, C.M. \& Sepkoski, J.J. 2005. Estimating paleodiversities: a test of the taxic and phylogenetic methods. Paleobiology, 31, 21-34.

Lang, W.H. 1926. Contributions to the study of the Old Red Sandstone flora of Scotland. III. On Hostimella (Ptilophyton) thomsoni, and its inclusion in a new genus, Milleria. IV. On a specimen of Protolepidodendron from the Middle Old Red Sandstone of Caithness. V. On the identification oh the large 'stems' in the Carmylie Beds of the Lower Old Red Sandstone as Nematophyton. Transactions of the Royal Society of Edinburgh, 54, 785-799. 
Leary, R.L. 1990. Possibly Early Pennsylvanian ancestor of the Cycadales. Science, 259, 1152-1154.

Leclercq, S. 1957. Étude d'une fructification de Sphenpside à structure conservée du dévonien supérieur. Mémoires d'Académie royaume Belge, Classe Science, 4, 1-39.

Leisman, G.A. 1964. Physostoma calcaratum sp. nov., a tentacled seed from the middle Pennsylvanian of Kansas. American Journal of Botany, 51, 1069-1075.

Leisman, G.A. \& Stidd, B.A. 1967. Further ocurrences of Spencerites from the Middle Pennsylvanian of Kansas and Illinois. American Journal of Botany, 54, 316-323.

Lemoigne, Y. \& Brown, J.T. 1980. Sur une flore à Glossopteridopsida et Lycopsida de Namibie (Sud-Oest africain). Geobios, 13, 541-553.

Li, C.S. 1982. Hsüa robusta, a new land plant from the Lower Devonian of Yunnan, China. Acta Phytotaxonomica Sinica, 8, 331-342.

Li, X. \& Yao, Z. 1983. Fructifications of gigantopterids from South China. Palaeontographica Abteilung B, 185, 11-26 [in Chinese].

Liu, Z.-H., Fls, C.-S.L. \& Fls, J.H. 2001. Fertile pinnules of Danaeites rigida $\mathrm{Gu}$ and Zhi (Marattiales) from the Upper Permian of south China. Botanical Journal of the Linnean Society, 136, 107-117.

Long, A.G. 1959. On the structure of Calymmatotheca kidstonii Calder (emended) and Genomosperma latens gen. et sp. nov. from the Calciferous Sandstone Series of Berwickshire. Transactions of the Royal Society of Edinburgh, 64, 29-44.

Long, A.G. 1961a. On the structure of Deltasperma fouldense gen. et sp. nov., and Camptosperma berniciense gen. et sp. nov., petrified seeds from the Calciferous Sandstone Series of Berwickshire. Transactions of the Royal Society of Edinburgh, 64, 281-295.

Long, A.G. 1961b. Some pteridosperm seeds from the Calciferous Sandstone Series of Berwickshire. Transactions of the Royal Society of Edinburgh, 64, 401-419.

Long, A.G. 1964. Some specimens of Stenomyelon and Kalymma from the Calciferous Sandstone Series of Berwickshire. Transactions of the Royal Society of Edinburgh, 65, 435-446.

Long, A.G. 1968a. Some specimens of Cladoxylon from the Calciferous Sandstone Series of Berwickshire. Transactions of the Royal Society of Edinburgh, 68, 45-61.

Long, A.G. 1968b. Some specimens of Mazocarpon, Achlamydocarpon and Cystosporites from the Lower Carboniferous rocks of Berwickshire. Transactions of the Royal Society of Edinburgh, 67, 359-372.

Long, A.G. 1975. Further observations on some Lower Carboniferous seeds and cupules. Transactions of the Royal Society of Edinburgh, 69, 267-293.

Long, A.G. 1976. Psalixochlaena berwickense sp. nov., a Lower Carboniferous fern from Berwickshire. Transactions of the Royal Society of Edinburgh, 69, 513-521.

Long, A.G. 1977. Observations on Carboniferous seeds of Mitrospermum, Conostoma and Lagenostoma. Transactions of the Royal Society of Edinburgh, 70, 37-61.
Mamay, S.H. 1962. Ocurrence of Pseudobornia Nathorst in Alaska. The Palaeobotanist, 11, 19-22.

Mapes, G. \& Rothwell, G.W. 1991. Structure and relationships of primitive conifers. Neues Jahrbuch für Geologie und Paläontologie, Abhandlungen, 183, 269-287.

Maridet, O., Escarguel, G., Costeur, L., Mein, P., Hugueney, M. \& Legendre, S. 2007. Small mammal (rodents and lagomorphs) European biogeography from the Late Oligocene to the mid Pliocene. Global Ecology and Biogeography, 16, 529-544.

Marshall, J.E.A. 1996. Rhabdosporites langii, Geminospora lemurata and Contagisporites optivus: An origin for heterospory within the Progymnosperms. Review of $\mathrm{Pa}$ laeobotany and Palynology, 93, 159-189.

Marui, Y., Chiba, S., Okuno, J. \& Yamasaki, K. 2004. Speciesarea curve for land snails on Kikai Island in geological time. Paleobiology, 30, 222-230.

McGhee, G.R. 1996. The Late Devonian extinction. Columbia University Press, New York, 303 pp.

Mei, M. 1984. The Analysis of the Floras of Permian Coalbearing Strata in Fujian, Jiangxi and Sichuan Provinces. Graduate School, China Institute of Mining, Beijing, 212 pp. [in Chinese].

Mertz, D.F., Swisher, C.C., Franzen, J.L., Neuffer, F.O. \& Lutz, H. 2000. Numerical dating of the Eckfeld maar fossil site, Eifel, Germany: a calibration mark for the Eocene time scale. Naturwissenschaften, 87, 270-274.

Meyen, S.V. 1979. Permian predecessors of the Mesozoic pteridosperms in western Angaraland. Review of Palaeobotany and Palynology, 28, 191-201.

Meyen, S.V. 1982. The Carboniferous and Permian floras of Angaraland (a synthesis). Biological Memoirs, 7, 1-109.

Meyen, S.V. 1983. Palaeontological Atlas for the Permian Strata of the Pechora Coal-Basin. Institute of Geology, USSR Academy of Science, Leningrad, 160 pp. [in Russian].

Meyen, S.V. 1987. Fundamentals of Palaeobotany. Chapman and Hall, London, 432 pp.

Meyen, S.V. 1988. Gymnosperms of the Angara flora. In: Origin and Evolution of Gymnosperms (Ed. C.B. Beck). Columbia University Press, New York, 338-381.

Meyen, S.V. \& Smoller, H.G. 1986. The genus Mostotchkia Chachlov (Upper Palaeozoic of Angaraland) and its bearing on the characteristics of the order Dicranophyllales (Pinopsida). Review of Palaeobotany and Palynology, 47, 205-223.

Miller, A.I. \& Foote, M. 1996. Calibrating the Ordovician Radiation of marine life: Implications for Phanerozoic diversity trends. Paleobiology, 22, 304-309.

Müller, A.H. 1961. Grossabláufe der Stammesgeschichte. Gustav Fischer, Jena, 116 pp.

Newell, N.D. 1952. Periodicity in invertebrate evolution. Journal of Paleontology, 26, 371-385.

Niklas, K.J. \& Banks, H.P. 1985. Evidence for xylem constrictions in the primary vasculature of Psilophyton dawsonii, an emsian trimerophyte. American Journal of Botany, 72, 674-685.

Novik, K.O. 1968. Flora from the Lower Carboniferous of the Donets Basin and its Western Continuation. Akademia Nauk Ukraine, Kiev, 234 pp. [in Russian]. 
Oliver, F.W. 1909. On Physostoma elegans, Williamson, an archaeic type of seed from the Palaeozoic rocks. Annals of Botany, 23, 73-116.

Palmqvist, P., Perez-Claros, J.A., Janis, C.M., Figueirido, B., Torregrosa, V. \& Grocke, D.R. 2008. Biogeochemical and ecomorphological inferences on prey selection and resource partitioning among mammalian carnivores in an early pleistocene community. Palaios, 23, 724-737.

Pant, D.D. \& Nautiyal, D.D. 1967. On the Structure of Buriadia heterophylla (Feistmantel) Seward and Sahni and its Fructification. Philosophical Transactions of the Royal Society of London B, 252 (774), 27-48.

Pfefferkorn, H.W. 1976. Pennsylvanian tree fern compressions Caulopteris, Megaphyton and Artisophyton gen. nov. in Illinois. Illinois State Geological Survey Circular, 492, 11-31.

Phillips, T.L. 1980. Stratigraphic and geographic occurrences of permineralized coal-swamp plants - Upper Carboniferous of North America and Europe. In: Biostratigraphy of Fossil Plants (Eds. D.L. Dilcher \& T.N. Taylor). Hutchinson and Ross, Stroudsburg, 25-92.

Phillips, T.L. \& Cecil, C.B. 1985. Paleoclimatic controls on coal resources of the pennsylvanian system of North America - Introduction and overview of contributions. International Journal of Coal Geology, 5, 1-6.

Phillips, T.L. \& Peppers, R.A. 1984. Changing patterns of Pennsylvanian coal-Swamp vegetation and implications of climatic control on coal occurrence. International Journal of Coal Geology, 3, 205-255.

Phillips, T.L., Peppers, R.A. \& Dimichele, W.A. 1985. Stratigraphic and interregional changes in Pennsylvanian coal -swamp vegetation- environmental inferences. International Journal of Coal Geology, 5, 43-109.

Pigg, K.B. \& Rothwell, G.W. 1983. Chaloneria gen. nov.; heterosporus lycophytes from the Pennsylvanian of North America. Botanical Gazette, 144, 132-147.

Radchenko, M.I. 1967. The Carboniferous Flora of Southeast Kazakhstan. Nauka Kazakhstan SSR, Alma Alta, 360 pp. [in Russian].

Raup, D.M. 1972. Taxonomic diversity during the Phanerozoic. Science, 117, 1065-1071.

Raup, D.M. 1975. Taxonomic survivorship curves and Van Valen's Law. Paleobiology, 1, 82-96.

Raup, D.M. 1978. Cohort analysis of generic survivorship. Paleobiology, 4, 1-15.

Raup, D.M. 1985. Mathematical models of cladogenesis. Paleobiology, 11, 42-52.

Raup, D.M. \& Boyajian, G.E. 1988. Patterns of generic extinction in the fossil record. Paleobiology, 14, 109-125.

Raup, D.M. \& Crick, R.E. 1979. Measurement of faunal similarity in paleontology. Journal of Paleontology, 53, 1213-1227.

Raup, D.M. \& Stanley, S.M. 1978. Principles of Paleontology. W.H. Freeman and Company, San Francisco, 481 pp.

Raymond, A. \& Metz, C. 1995. Laurussian land plant diversity during the Silurian and Devonian: mass extinction, sampling bias, or both? Paleobiology, 21, 74-91.

Rayner, R.J. 1985. The Permian lycopod Cyclodendron leslii from South Africa. Palaeontology, 28, 111-120.
Remy, R. 1961. Beiträge zur Flora des Autunien. Monatsbericht der Deutschen Akademie der Wissenschaften zu Berlin, 3, 331-336.

Remy, W. \& Spassov, C. 1959. Der paläobotanische Nachweiss von Oberdevon in Bulgarien. Monatsbericht der Deutschen Akademie der Wissenschaften zu Berlin, 1, 384-386.

Renault, B. 1890. Étude ser le terrain houiller de Commentry. Livre 2è: flore fossile, 2è partie. Bulletin de la Societé Industrie Minière, 4, 381-712.

Robeck, H.E., Maley, C.C. \& Donoghue, M.J. 2000. Taxonomy and temporal diversity patterns. Paleobiology, 26, 171-187.

Roth, A. \& Mosbrugger, V. 1996. Numerical studies of water conduction in land plants: Evolution of early stele types. Paleobiology, 22, 411-421.

Roth-Nebelsick, A., Grimm, G., Mosbrugger, V., Hass, H. \& Kerp, H. 2000. Morphometric analysis of Rhynia and Asteroxylon: testing functional aspects of early land plant evolution. Paleobiology, 26, 405-418.

Rothwell, G.W. 1996. Pteridophytic evolution: An often underappreciated phytological success story. Review of Palaeobotany and Palynology, 90, 209-222.

Rothwell, G.W. 1999. Fossils and ferns in the resolution of land plant phylogeny. Botanical Review, 65, 188-218.

Rothwell, G.W., Scheckler, S.E. \& Gillespie, W.H. 1989. Elkinsia gen. nov., a Late Devonian gymnosperm with cupulate ovules. Botanical Gazette, 150, 170-189.

Rousseau, A. 1933. Contribution à l'étude de Pinakodendron ohmanni Weiss. Mémoires du Musée Royal d'Histoire Naturelle de Belgique, 59, 1-32.

Ruíz, F., Rodríguez-Ramírez, A., Cáceres, L.M., Vidal, J.R., Carretero, M.I., Clemente, L., Muñoz, J.M., Yanez, C. \& Abad, M. 2004. Late Holocene evolution of the southwestern Doñana National Park (Guadalquivir Estuary, SW Spain): a multivariate approach. Palaeogeography, $\mathrm{Pa}$ laeoclimatology, Palaeoecology, 204, 47-64.

Scheckler, S.E. \& Galtier, J. 2003. Tyloses and ecophysiology of the early carboniferous progymnosperm tree Protopitys buchiana. Annals of Botany 91, 739-747.

Schindewolf, O.H. 1962. Neokatastrophismus? Deutsche Geologische Gesellschaft Zeitschrift, 114, 430-445.

Schweitzer, H.-J. 1967. Die Oberdevon-Flora der Bärinsel, 1. Pseudobornia ursina Nathorst. Palaeontographica Abteilung B, 120, 116-137.

Schweitzer, H.-J. 1972. Die Mitteldevon-Flora von Lindlar (Rheinland). 3. Filicinae - Hyenia elegans Kräusel and Weyland. Palaeontographica Abteilung B, 137, 154-175.

Schweitzer, H.-J. 1973. Die Mitteldevon-Flora von Lindlar (Rheinland). 4. Filicinae - Calamophyton primaevum Kräusel and Weyland. Palaeontographica Abteilung B, 140, 117-150.

Scott, A.C. \& Galtier, J. 1985. Distribution and ecology of early ferns. Proceedings of the Royal Society of Edinburgh $B$, 86, 289-301.

Scott, A.C., Galtier, J. \& Clayton, G. 1984. Distribution of anatomically-preserved floras in the Lower Carboniferous in western Europe. Transactions of the Royal Society of Edinburgh, 75, 311-340. 
Scott, A.C., Galtier, J. \& Clayton, G. 1985. A new Late Tournaisian (Lower Carboniferous) flora from the Kilpatrick Hills, Scotland. Review of Palaeobotany and Palynology, 44, 81-99.

Scott, D.H. 1898. On the structure and affinities of fossil plants from the Palaeozoic rocks. Pt 1. On Cheirostrobus. Philosophical Transactions of the Royal Society of London $B, 189,1-34$.

Sepkoski, J.J. 1978. A kinetic-model of phanerozoic taxonomic diversity I. Analysis of marine orders. Paleobiology, 4, 223-251.

Sepkoski, J.J. 1979. A kinetic-model of phanerozoic taxonomic diversity II. Early phanerozoic families and multiple equilibria. Paleobiology, 5, 222-251.

Sepkoski, J.J. 1984. A kinetic-model of phanerozoic taxonomic diversity III. Post-Paleozoic families and mass extinctions. Paleobiology, 10, 246-267.

Sepkoski, J.J., Jr. 1987. Environmental trends in extinction during the Paleozoic. Science, 235, 64-6.

Sepkoski, J.J., Jr. 1988. Extinctions of life. Los Alamos Science, 16, 36-49.

Sepkoski, J.J., Jr. 1993. Ten years in the library: new data confirm paleontological patterns. Paleobiology, 19, 43-51.

Sepkoski, J.J., Jr. 1994. Extinction and the fossil record. Geotimes, 39 (3), 15-17.

Sepkoski, J.J., Jr. 1997. Biodiversity: Past, present, and future. Journal of Paleontology, 71, 533-539.

Sepkoski, J.J., Jr. 1998. Rates of speciation in the fossil record. Philosophical Transactions of the Royal Society of London B, 353 (1366), 315-26.

Sepkoski, J.J. \& Kendrick, D.C. 1993. Numerical experiments with model monophyletic and paraphyletic taxa. Paleobiology, 19, 168-184.

Sepkoski, J.J., McKinney, F.K. \& Lidgard, S. 2000. Competitive displacement among post-Paleozoic cyclostome and cheilostome bryozoans. Paleobiology, 26, 7-18.

Shadle, G.L. \& Stidd, B.M. 1975. The frond of Heterangium. American Journal of Botany, 62, 67-75.

Shi, G.R. 1993. A comprensive study of 39 binary similarity coefficients. Memoirs of the Association of Australasian Palaeontologists, 15, 329-341.

Shute, C.H. \& Cleal, C.J. 2002. Ecology and growth habit of Laveineopteris: A gymnosperm from the Late Carboniferous tropical rain forests. Palaeontology, 45, 943-972.

Simpson, G.G. 1953. The Major Features of Evolution. Columbia University Press, New York, 434 pp.

Skog, J.E. \& Banks, H.P. 1973. Ibykia amphikoma, gen. et sp. n., a new protoarticulate precursor from the late Middle Devonian of New York State. American Journal of Botany, 60, 366-80.

Smith, D.L. 1962. Three fructifications from the Scottish Lower Carboniferous. Palaeontology, 5, 225-237.

Stewart, W.N. \& Rothwell, G.W. 1993. Paleobotany and the Evolution of Plants. Cambridge University Press, Cambridge, $521 \mathrm{pp}$.

Stidd, B.M. 1978. An anatomically preserved Potoniea with in situ spores from the Pennsylvanian of Illinois. American Journal of Botany, 65, 667-683.
Stidd, B.M., Oestry, L.L. \& Phillips, T.L. 1975. On the frond of Sutcliffia insignis var. tuberculata. Review of Palaeobotany and Palynology, 20, 55-66.

Stockmans, F. \& Mathieu, F.-F. 1939. La Flore paléozoïque du Bassin houiller de Kaiping (Chine). Musée Royal d'Histoire Naturelle de Belgique, Brussels, 165 pp.

Stockmans, F. \& Mathieu, F.-F. 1957. La flore paléozoïque du Bassin houiller de Kaiping (Chine) (Deuxième partie). Association pour l'Étude de la Paléontologie et de la Stratigraphie Houillères, 32, 1-89.

Stockmans, F. \& Willière, Y. 1953. Végétaux namuriens de la Belgique. Association pour l'Étude de la Paléontologie et de la Stratigraphie Houillères, 13, 1-382.

Stockmans, F. \& Willière, Y. 1955. Végétaux Namuriens de la Belgique. Assise de Chokier, Zone de Bioul. Association pour l'Étude de la Paléontologie et de la Stratigraphie Houillères, 23, 1-35.

Stoneley, H.M.M. 1958. The Upper Permian flora of England. Bulletin of the British Museum (Natural History) Geology, 3, 293-337.

Stubblefield, S.P. \& Banks, H.P. 1978. The cuticule of Drepanophicus spinaeformis, a long-ranging Devonian lycopod from New York and eastern Canada. American Journal of Botany, 65, 100-118.

Stubblefield, S.P. \& Rothwell, G.W. 1981. Embryology and reproductive biology of Bothrodendrostrobus mundus (Lycopsida). American Journal of Botany, 68, 625-634.

Stubblefield, S.P. \& Rothwell, G.W. 1989. Cecropsis luculentum gen. et sp. nov.: evidence for heterosporous progymnosperms in the Upper Pennsylvanian of North America American Journal of Botany, 76, 1415-1428.

Taylor, T.N. 1969. Cycads: evidence from the Upper Pennsylvanian. Science, 164, 294-295.

Taylor, T.N. \& Eggert, D.A. 1967. Petrified plants from the Upper Mississippian of North America. I: The seed Rhynchosperma gen. n. American Journal of Botany, 54, 984-992.

Taylor, T.N. \& Taylor, E.L. 1993. The Biology and Evolution of Fossil Plants. Prentice-Hall, Englewood Cliffs, New Jersey, 982 pp.

Taylor, T.N., Taylor, E.L. \& Krings, M. 2009. Paleobotany: the biology and evolution of fossil plants. Academic Press, Burlington, $1252 \mathrm{pp}$.

Thomas, B.A. 2007. Phytogeography of Asturian (Westphalian D) lycophytes throughout the Euramerican belt of coalfields. Geological Magazine, 144, 457-463.

Thomas, B.A. \& Brack-Hanes, S.D. 1984. A new approach to family grouping in the lycophytes. Taxon, 33, 247-255.

Tian, B.-L. \& Guo, Y.-T. 1987. A new species of lepidodendroid fructification - Achlamydocarpon sinensis. Acta Botanica Sinica, 29, 218-222 [in Chinese].

Tidwell, W.D. 1967. Flora of the Manning Canyon Shale. Part I: A Lowermost Pennsylvanian flora from the Manning Canyon Shale, Utah, and its stratigraphic significance. Brigham Young University Geology Studies, 14, 3-66.

Townrow, J.A. 1956. On some species of Phyllotheca Journal and Proceedings of the Royal Society of New South Wales, 89, 39-63. 
Townrow, J.A. 1967. On Rissikia and Mataia podocarpaceous conifers from the Lower Mesozoic of southern lands. $\mathrm{Pa}$ pers and Proceedings of the Royal Society of Tasmania, 101, 103-136.

Utting, J. \& Neves, R. 1970. Palynology of the Lower Limestone Shale Group (Basal Carboniferous Limestone series) and Portishead Beds (Upper Old Red Sandstone). In: Colloque sur la Stratigraphie du Carbonifère. Congrès et Colloques (Eds. M. Streel \& R.H. Wagner). Université de Liège, Liège, 411-427 pp.

Vakhrameev, V.A., Dobruskina, I.A., Meien, S.V. \& Zaklinskaya, E.D. 1978. Paläozoische und Mesozoische Floren Eurasiens und die Phytogeographie Dieser Zeit. Gustav Fisher, Jena, 300 pp.

Valentine, J.W. 1969. Patterns of taxonomic ecologic structure of the shelf benthos during Phanerozoic time. Palaeontology, 12, 684-709.

Valentine, J.W. \& Jablonski, D. 2003. Morphological and developmental macroevolution: a paleontological perspective. International Journal of Developmental Biology, 47, 517-522.

Valentine, J.W. \& May, C.L. 1996. Hierarchies in biology and paleontology. Paleobiology, 22, 23-33.

Van Valen, L. 1972. Laws in biology and history: structural similarities of academic disciplines. New Literary History, 3, 309-419.

Van Valen, L. 1973a. Are categories in different phyla comparable? Taxon, 22, 333-373.

Van Valen, L. 1973b. A new evolutionary law. Evolutionary Theory, 1, 1-30.

Wagner, R.H. 1983. Upper Stephanian stratigraphy and palaeontology of the Puertollano Basin, Ciudad Real, Spain. Anais da Faculdade de Ciências, Porto, 64 supplement, 171-231.

Wagner, R.H. 1984. Megafloral zones of the Carboniferous. Compte rendu 9e Congrès International de Stratigraphie et de Géologie du Carbonifère, 2, 109-134.

Wagner, R.H. \& Álvarez-Vázquez, C. 2008. A revision of the Lower Pennsylvanian Alethopteris lonchitica (autoctorum) and its identity with Alethopteris urophylla. Revista Española de Paleontología, 23, 157-192.

Wagner, R.H., Winkler Prins, C.F. \& Granados, L.F. 1983. The Carboniferous of the World. I. China, Korea, Japan and S. E. Asia. Instituto Geológico y Minero de España, Madrid, 243 pp.

Walton, J. 1931. Contributions to the Knowledge of Lower Carboniferous plants. Part III. Philosophical Transactions of the Royal Society of London B, 219, 347-379.

Walton, J. 1949a. Calathospermum scoticum - an ovuliferous fructification of Lower Carboniferous age from Dumbartonshire. Transactions of the Royal Society of Edinburgh, 61, 719-728.

Walton, J. 1949b. A petrified example of Alcicornopteris (Alcicornopteris hallei sp. nov.) from Lower Carboniferous of Dumbartonshire. Annals of Botany, 13, 445-452.

Wang, S.C. \& Bush, A.M. 2009. Adjusting global extinction rates to account for taxonomic susceptibility. Paleobio$\log y, \mathbf{3 4}, 434-455$.

Willis, K.J. \& McElwain, J. 2002. The evolution of plants. Oxford University Press, Oxford, 378 pp.

Willis, K.J., Araújo, M.B., Bennett, K.D., Figueroa-Rangel, B., Froyd, C.A. \& Myers, N. 2007. How can a knowledge of the past help to conserve the future? Biodiversity conservation and the relevance of long-term ecological studies Philosophical Transactions of the Royal Society of London B, 362, 175-186.

Zhao, X., Mo, Z. \& Zhang, S. 1980. Late Permian Flora from W. Guizhou and E. Yunnan. In: Stratigraphy and Palaeontology of Upper Permian Coal Measures in $W$ Guizhou and E Yunnan (Ed. Nanjing Institute of Geology and Palaeontology). Scientific Press, Beijing, 70-122.

Zimmermann, F. 1930. Zur Kenntnis von Eleutherophyllum mirabile (Sternberg) Stur ('Equisetites' mirabilis Sternberg). Arbeit der Institut Paläobotanik und Petrographie der Brennsteine, 2, 83-102.

Manuscrito recibido: 4 de Diciembre, 2009 Manuscrito aceptado: 4 de Mayo, 2010 
Table S1. Families and main predominant types of fossil compilated to codify the binary matrix of the analyses. The families appear by alphabetic order. For more detail see consulted sources in Material and Methods.

\begin{tabular}{|c|c|c|}
\hline FAMILY & $\begin{array}{l}\text { TYPE OF } \\
\text { FOSSIL }\end{array}$ & REFERENCES \\
\hline \multirow{2}{*}{ Aneurophytaceae } & Fertile parts & Bonamo \& Banks, 1967 \\
\hline & Stems & Lang, 1926 \\
\hline \multirow{4}{*}{ Arberiaceae } & \multirow{2}{*}{ Foliages } & Delevoryas \& Person, 1975 \\
\hline & & Vakhrameev et al., 1978 \\
\hline & Pollen organ & Delevoryas \& Gould, 1971 \\
\hline & Fructifications & Anderson \& Anderson, 1985 \\
\hline \multirow{3}{*}{ Archaeocalamitaceae } & Fructifications & Scott et al., 1985 \\
\hline & \multirow{2}{*}{ Stems } & Ischenko, 1965 \\
\hline & & Novik, 1968 \\
\hline \multirow[b]{2}{*}{ Archaeopteridaceae } & Foliages & Allen \& Marshall, 1986 \\
\hline & $\begin{array}{c}\text { Reproductive } \\
\text { structures }\end{array}$ & Chaloner, 1968 \\
\hline \multirow{2}{*}{ Asterothecaceae } & Axes & Pfefferkorn, 1976 \\
\hline & Fructifications & Phillips, 1980 \\
\hline \multirow{2}{*}{ Biscalithecaceae } & Fronds & Galtier, 1978 \\
\hline & Sporangia & Galtier \& Scott, 1979 \\
\hline \multirow{3}{*}{ Botryopteridaceae } & \multirow{3}{*}{ Fructifications } & Galtier, 1967 \\
\hline & & Galtier, 1971 \\
\hline & & Scott et al., 1985 \\
\hline \multirow{4}{*}{ Bowmanitaceae } & \multirow{2}{*}{ Sterile foliages } & Remy, 1961 \\
\hline & & Remy \& Spassov, 1959 \\
\hline & \multirow{2}{*}{ Strobilies } & Remy, 1961 \\
\hline & & Remy \& Spassov, 1959 \\
\hline Buriadiaceae & Fructifications & Pant \& Nautiyal, 1967 \\
\hline \multirow{4}{*}{ Calamopityaceae } & \multirow{2}{*}{ Fructifications } & Galtier \& Rowe, 1989 \\
\hline & & Walton, 1949b \\
\hline & Foliages & Walton, 1931 \\
\hline & Stem & Long, 1964 \\
\hline \multirow{2}{*}{ Calamostachyaceae } & \multirow{2}{*}{ Sterile foliages } & Kerp, 1984 \\
\hline & & Stockmans \& Willière, 1953 \\
\hline \multirow{2}{*}{ Callistophytaceae } & Stems & Phillips, 1980 \\
\hline & Pollen organ & Phillips, 1980 \\
\hline \multirow{2}{*}{ Cardiolepidiaceae } & Foliages fragments & Meyen, 1983 \\
\hline & Fructifications & Meyen, 1983, 1988 \\
\hline Caudatocarpaceae & $\begin{array}{c}\text { Reproductive } \\
\text { structures }\end{array}$ & Brack-Hanes, 1981 \\
\hline Cecropsidaceae & Leaves & Stubblefield \& Rothwell, 1989 \\
\hline \multirow{3}{*}{ Chaloneriaceae } & \multirow{2}{*}{ Cones } & Chaloner, 1958 \\
\hline & & Crookall, 1966 \\
\hline & $\begin{array}{l}\text { Reproductive } \\
\text { structures }\end{array}$ & Pigg \& Rothwell, 1983 \\
\hline Cheirostrobaceae & $\begin{array}{l}\text { Reproductive } \\
\text { structures }\end{array}$ & Scott, 1898 \\
\hline
\end{tabular}

\begin{tabular}{|c|c|c|}
\hline FAMILY & $\begin{array}{l}\text { TYPE OF } \\
\text { FOSSIL }\end{array}$ & REFERENCES \\
\hline \multirow{4}{*}{ Cladoxylaceae } & \multirow{2}{*}{$\begin{array}{l}\text { Reproductive } \\
\text { structures }\end{array}$} & Long, 1968a \\
\hline & & Schweitzer, 1972, 1973 \\
\hline & \multirow{2}{*}{ Vegetative organs } & Long, 1968a \\
\hline & & Schweitzer, 1972, 1973 \\
\hline \multirow{2}{*}{ Cordaitanthaceae } & Foliages & Mei, 1984 \\
\hline & Seeds & Long, 1977 \\
\hline \multirow{3}{*}{ Corynepteridaceae } & Fertile foliages & Galtier \& Scott, 1979 \\
\hline & Fructifications & Scott et al., 1985 \\
\hline & Sterile foliages & Stockmans \& Willière, 1955 \\
\hline Crossothecaceae & Foliages & Brousmiche, 1983 \\
\hline \multirow{3}{*}{ Cycadaceae } & Leaves & Leary, 1990 \\
\hline & Pollen cones & Taylor, 1969 \\
\hline & Seeds & Leary, 1990 \\
\hline Cyclodendraceae & Sterile stems & Rayner, 1985 \\
\hline Cyclostigmaceae & Fertile structures & Chaloner, 1968 \\
\hline \multirow{2}{*}{ Diaphorodendraceae - } & Stems & DiMichele \& Bateman, 1992 \\
\hline & Axes & DiMichele \& Bateman, 1992 \\
\hline \multirow{4}{*}{ Dicranophyllaceae } & \multirow{2}{*}{ Foliages } & Meyen \& Smoller, 1986 \\
\hline & & Stockmans \& Willière, 1953 \\
\hline & \multirow{2}{*}{ Fructifications } & Meyen \& Smoller, 1986 \\
\hline & & Renault, 1890 \\
\hline \multirow{2}{*}{ Drepanophycaceae } & \multirow{2}{*}{ Sterile axes } & Stubblefield \& Banks, 1978 \\
\hline & & Kräusel \& Weyland, 1937 \\
\hline Echinostachyaceae & $\begin{array}{c}\text { Reproductive } \\
\text { structures }\end{array}$ & Grauvogel-Stamm, 1978 \\
\hline \multirow{4}{*}{ Eleutherophyllaceae } & \multirow{2}{*}{$\begin{array}{l}\text { Reproductive } \\
\text { structures }\end{array}$} & Josten, 1983 \\
\hline & & Zimmermann, 1930 \\
\hline & \multirow{2}{*}{ Vegetative organs } & Josten, 1983 \\
\hline & & Zimmermann, 1930 \\
\hline \multirow{3}{*}{ Elkinsiaceae } & Fructifications & Walton, 1949a \\
\hline & $\begin{array}{c}\text { Reproductive } \\
\text { structures }\end{array}$ & Rothwell et al., 1989 \\
\hline & Seeds & Long, $1961 \mathrm{~b}$ \\
\hline \multirow{4}{*}{ Emplectopteridaceae- } & Fronds & Halle, 1927 \\
\hline & Fructifications & Li \& Yao, 1983 \\
\hline & Leaves & Asama, 1962 \\
\hline & Seeds & Halle, 1932 \\
\hline Emporiaceae & $\begin{array}{c}\text { Reproductive } \\
\text { structures }\end{array}$ & Mapes \& Rothwell, 1991 \\
\hline \multirow{2}{*}{ Eospermaceae } & \multirow{2}{*}{ Seeds } & Long, 1961a \\
\hline & & Barnard, 1959 \\
\hline \multirow{4}{*}{ Equisetaceae } & Foliar whorls & Escapa \& Cúneo, 2006 \\
\hline & Esterile stems & Kon'no, 1973 \\
\hline & \multirow{2}{*}{ Fertile structures } & Escapa \& Cúneo, 2006 \\
\hline & & Kon'no, 1962 \\
\hline
\end{tabular}




\begin{tabular}{|c|c|c|}
\hline FAMILY & $\begin{array}{l}\text { TYPE OF } \\
\text { FOSSIL }\end{array}$ & REFERENCES \\
\hline Eviostachyaceae & Fructifications & Leclercq, 1957 \\
\hline Ferugliocladaceae & $\begin{array}{l}\text { Reproductive } \\
\text { structures }\end{array}$ & Archangelsky \& Cúneo, 1987 \\
\hline \multirow{2}{*}{ Flemingitaceae } & Megaspores & Chaloner, 1953 \\
\hline & Stems & Zhao et al., 1980 \\
\hline Genomospermaceae & $\begin{array}{c}\text { Reproductive } \\
\text { structures }\end{array}$ & Long, 1959 \\
\hline \multirow{4}{*}{ Gleicheniaceae } & \multirow{2}{*}{ Sporangia } & Ash, 1969 \\
\hline & & Halle, 1927 \\
\hline & \multirow{2}{*}{ Vegetative organs } & Ash, 1969 \\
\hline & & Halle, 1927 \\
\hline Gondwanostachyaceae & Foliages & Townrow, 1956 \\
\hline Horneophytaceae & Sporangia & El-Saadway \& Lacey, 1979 \\
\hline \multirow{2}{*}{ Ibykaceae } & \multirow{2}{*}{ Stems } & Bertrand, 1913 \\
\hline & & Skog \& Banks, 1973 \\
\hline Isoetaceae & $\begin{array}{l}\text { Reproductive } \\
\text { structures }\end{array}$ & Stubblefield \& Rothwell, 1981 \\
\hline \multirow{2}{*}{ Lagenostomaceae } & Fronds & Shadle \& Stidd, 1975 \\
\hline & Seeds & Long, 1975 \\
\hline Lepidocarpaceae & Fructifications & Tian \& Guo, 1987 \\
\hline Lycopodiaceae & Sterile axes & Kräusel \& Weyland, 1937 \\
\hline \multirow{2}{*}{ Majonicaceae } & \multirow{2}{*}{$\begin{array}{l}\text { Reproductive } \\
\text { structures }\end{array}$} & Clement-Westerhof, 1987 \\
\hline & & Stoneley, 1958 \\
\hline \multirow{4}{*}{ Marattiaceae } & Fertile pinnules & Zhao-Hua et al., 2000 \\
\hline & \multirow{2}{*}{ Fronds } & Hill et al., 1985 \\
\hline & & Hill \& Camus, 1986 \\
\hline & Sporangia & Hill et al., 1985 \\
\hline Miadesmiaceae & Sterile fragments & Bertrand, 1895 \\
\hline Nilsoniaceae & Leaves & Kimura \& Okubo, 1985 \\
\hline \multirow{2}{*}{ Noeggerathiaceae } & Fertile structures & Hirmer, 1941 \\
\hline & Foliages & Gothan, 1931 \\
\hline Osmundaceae & Fronds & $\begin{array}{c}\text { Kidston \& Gwynne-Vaughan, } \\
\text { 1908a, 1908b } \\
\end{array}$ \\
\hline \multirow{2}{*}{ Peltaspermaceae } & \multirow{2}{*}{ Foliages } & Kerp \& Naugolnykh, 1996 \\
\hline & & Bouroz \& Doubinger, 1977 \\
\hline \multirow{3}{*}{ Physostomaceae } & \multirow{3}{*}{ Seeds } & Gordon, 1910 \\
\hline & & Leisman, 1964 \\
\hline & & Oliver, 1909 \\
\hline \multirow{4}{*}{ Pinakodendraceae } & \multirow{2}{*}{$\begin{array}{l}\text { Reproductive } \\
\text { structures }\end{array}$} & Kidston, 1911 \\
\hline & & Rousseau, 1933 \\
\hline & \multirow{2}{*}{ Vegetative organs } & Kidston, 1911 \\
\hline & & Rousseau, 1933 \\
\hline Pleuromeiaceae & $\begin{array}{l}\text { Reproductive } \\
\text { structures }\end{array}$ & $\begin{array}{c}\text { Grauvogel-Stamm \& Duringer, } \\
1983\end{array}$ \\
\hline \multirow{3}{*}{ Podocarpaceae } & \multirow{2}{*}{ Foliages } & Carpentier, 1935 \\
\hline & & Townrow, 1967 \\
\hline & Fructifications & Townrow, 1967 \\
\hline
\end{tabular}

\begin{tabular}{|c|c|c|}
\hline FAMILY & $\begin{array}{c}\text { TYPE OF } \\
\text { FOSSIL }\end{array}$ & REFERENCES \\
\hline \multirow{6}{*}{ Potoniaceae } & \multirow{2}{*}{ Foliages } & Bouroz \& Doubinger, 1977 \\
\hline & & Wagner et al., 1983 \\
\hline & Fronds & Stidd et al., 1975 \\
\hline & Fructifications & Stockmans \& Willière, 1953 \\
\hline & Seeds & Phillips, 1980 \\
\hline & Spores & Stidd, 1978 \\
\hline \multirow{2}{*}{ Protokalonaceae } & Stems & Barnard \& Long, 1975 \\
\hline & Branches & Barnard \& Long, 1975 \\
\hline \multirow{2}{*}{ Protolepidodendraceae- } & Sterile stems & Lemoigne \& Brown, 1980 \\
\hline & Fructifications & Smith, 1962 \\
\hline Protopityaceae & Fructifications & Smith, 1962 \\
\hline \multirow{4}{*}{ Psalixochlaenaceae - } & Fronds & Holmes, 1981 \\
\hline & Fertile parts & Holmes, 1981 \\
\hline & Sporangia & Good, 1981 \\
\hline & Vegetative axes & Long, 1976 \\
\hline \multirow{4}{*}{ Pseudoborniaceae } & \multirow{2}{*}{ Stems } & Mamay, 1962 \\
\hline & & Schweitzer, 1967 \\
\hline & \multirow{2}{*}{ Leaves } & Mamay, 1962 \\
\hline & & Schweitzer, 1967 \\
\hline \multirow{2}{*}{ Rhacophytaceae } & Fertile structures & Wagner, 1984 \\
\hline & Pollen grains & Utting \& Neves, 1970 \\
\hline \multirow{3}{*}{ Rhyniaceae } & Sporangia & Edwards et al., 1992 \\
\hline & \multirow{2}{*}{ Stems } & Edwards \& Richardson, 2004 \\
\hline & & Li, 1982 \\
\hline \multirow{2}{*}{ Rufloriaceae } & Foliages & Meyen, 1982 \\
\hline & Fructifications & Gorelova et al., 1973 \\
\hline Selaginellaceae & $\begin{array}{l}\text { Reproductive } \\
\text { structures }\end{array}$ & Fairon-Demaret, 1977 \\
\hline Sermeyaceae & Sporangia & Eggert \& Delevoryas, 1967 \\
\hline \multirow{2}{*}{ Sigillariostrobaceae - } & Specimens & Long, $1968 \mathrm{~b}$ \\
\hline & Sterile stems & Feng et al., 1977 \\
\hline \multirow[t]{2}{*}{ Spenceritaceae } & $\begin{array}{l}\text { Reproductive } \\
\text { structures }\end{array}$ & Leisman \& Stidd, 1967 \\
\hline & Spores & Kubart, 1910 \\
\hline Sporangiostrobaceae & $\begin{array}{l}\text { Reproductive } \\
\text { structures }\end{array}$ & Wagner, 1983 \\
\hline \multirow{4}{*}{ Stauropteridaceae } & \multirow{2}{*}{$\begin{array}{l}\text { Reproductive } \\
\text { structures }\end{array}$} & Cichan \& Taylor, 1982 \\
\hline & & Erwin \& Rothwell, 1989 \\
\hline & \multirow{2}{*}{ Vegetative organs } & Cichan \& Taylor, 1982 \\
\hline & & Erwin \& Rothwell, 1989 \\
\hline Takhtajanodoxaceae & $\begin{array}{l}\text { Reproductive } \\
\text { structures }\end{array}$ & Thomas \& Brack-Hanes, 1984 \\
\hline \multirow{2}{*}{ Tchernoviaceae } & Fructifications & Meyen, 1982 \\
\hline & Sterile foliages & Radchenko, 1967 \\
\hline \multirow{3}{*}{ Tedeleaceae } & \multirow{3}{*}{ Fructifications } & Barthel, 1976 \\
\hline & & Meyen, 1987 \\
\hline & & Scott et al., 1985 \\
\hline
\end{tabular}




\begin{tabular}{|c|c|c|}
\hline FAMILY & $\begin{array}{c}\text { TYPE OF } \\
\text { FOSSIL } \\
\end{array}$ & REFERENCES \\
\hline \multirow{6}{*}{ Tingiostachyaceae } & \multirow{2}{*}{ Foliages } & Halle, 1927 \\
\hline & & Stockmans \& Mathieu, 1939 \\
\hline & $\begin{array}{c}\text { Reproductive } \\
\text { structures }\end{array}$ & Stockmans \& Mathieu, 1957 \\
\hline & \multirow{2}{*}{ Sterile foliages } & Feng et al., 1977 \\
\hline & & Kon'no et al., 1971 \\
\hline & Sterile fragments & Tidwell, 1967 \\
\hline \multirow{2}{*}{ Trichopityaceae } & \multirow{2}{*}{ Foliages } & Cridland \& Morris, 1963 \\
\hline & & Meyen, 1987 \\
\hline \multirow{3}{*}{ Trigonocarpaceae } & Foliage & Wagner et al., 1983 \\
\hline & Seeds & Taylor \& Eggert, 1967 \\
\hline & Stems & Barthel, 1976 \\
\hline \multirow{3}{*}{ Trimerophytaceae } & Sporangia & Croft \& Lang, 1942 \\
\hline & \multirow{2}{*}{ Stems } & Gerrienne, 1983 \\
\hline & & Kaspar et al., 1988 \\
\hline Ullmanniaceae & $\begin{array}{c}\text { Reproductive } \\
\text { structures }\end{array}$ & Clement-Westerhof, 1988 \\
\hline Umkomasiaceae & Foliages & Meyen, 1979 \\
\hline \multirow{2}{*}{ Urnatopteridaceae } & \multirow{2}{*}{ Foliages } & Kerp \& Fichter, 1985 \\
\hline & & Stockmans \& Willière, 1953 \\
\hline Utrechtiaceae & $\begin{array}{c}\text { Reproductive } \\
\text { structures } \\
\end{array}$ & Mapes \& Rothwell, 1991 \\
\hline Vojnovskyaceae & Leaves & Vakhrameev et al., 1978 \\
\hline Voltziaceae & $\begin{array}{c}\text { Reproductive } \\
\text { structures }\end{array}$ & Clement-Westerhof, 1988 \\
\hline \multirow{2}{*}{ Zosterophyllaceae } & Sporangia & Edwards, 1972, 1975 \\
\hline & Stems & Hueber, 1971, 1972 \\
\hline \multirow{5}{*}{ Zygopteridaceae } & Fertile structures & Scott et al., 1984 \\
\hline & Fructifications & Scott et al., 1985 \\
\hline & \multirow{2}{*}{ Stems } & Galtier \& Scott, 1979 \\
\hline & & Scott \& Galtier, 1985 \\
\hline & Sterile foliages & Scott et al., 1985 \\
\hline
\end{tabular}

